\title{
IMPROVING ENGLISH LANGUAGE ABILITY OF CHILDREN AgED 4-5 YeARS OLd BY USING CREATIVE DANCE
}

\author{
Sabila Nur Masturah ${ }^{1)}$, Myrnawati Crie Handini ${ }^{2)}$, Sofia Hartati ${ }^{3)}$, Elindra Yetti ${ }^{4)}$ \\ 1) State University of Jakarta, Jakarta, Indonesia \\ E-mail: sabilanurm@gmail.com \\ 2) State University of Jakarta, Jakarta, Indonesia \\ E-mail:myrnawati48@gmail.com \\ 3) State University of Jakarta, Jakarta, Indonesia \\ E-mail:sofiapaud@yahoo.com \\ 4) State University of Jakarta, Jakarta, Indonesia \\ E-mail: elindrayetti@gmail.com
}

\begin{abstract}
The aim of this research is to know about how to improve English language ability of children aged 4-5 years old by using creative dance. The subjects of this research were seven children in group A at Bilingual Kindergarten Rumah Pelangi Pondok Bambu, East Jakarta. This research was held during April-June, 2016. The method used is classroom action research proposed by Kemmis and Taggart in two cycles. Each cycle consists of planning, acting, observing, and reflecting. The children's English language ability was still low. The presentation of success dealt between the researcher and collaborator was $71 \%$. The result of data analysis of pre-research was $42,1 \%$. After being given the action, the percentage increased to $61,87 \%$. The data got from the first cycle has not achieved its target, so the researcher conducted the second cycle. The result was $80,41 \%$. Based on the result in the second cycle, the hypothesis is proved. Qualitatively, it is also admitted that the children's English language ability could improve their creative movement.source language using the incorrect grammatical, the sentence is vague, the idea is not coherent and many pungtuations .
\end{abstract}

Keywords: English Ability, Creative Dance, Children

\section{INTRODUCTION}

Some Indonesian people still do not master English, whereas English has become a universal language and important in this globalization era. English is a foreign language in our country as said by the Constitutions, year 2009, number 24, which is a language other than Indonesian and local languages. In addition, Indonesia has provided facilities to assist the global competition as stipulated in the Constitutions, year 2009, number 24 about Flag, Language, and National Emblem, and National Anthem, article 43, paragraph 1 that the government can facilitate Indonesian citizens who want to have foreign language competence in order to increase national competitiveness. According to Yusuf English is used as the language medium of instructions for today's generation to be able to have access on the development of knowledge more widely for the sake of national acceleration. Teachers can encourage language development where newly introduced vocabularies can have meaning. Furthermore, Hapsari \& Suminar Said that the understanding of English vocabularies should be done from an early age; especially the golden age for learning a language other than mother tongue (Indonesian). Since English is a language that will become the language medium of instructions, and has also become an international language, it is better learned as early as possible. 
There are still a few kindergartens which apply English learning. It causes the aforementioned dilemma that only a few Indonesian children who master English in certain kindergartens who apply English learning. English is different from the Indonesian language because it is a foreign language, whereas the mastery of foreign languages becomes one of the important aspects as the main modal to produce qualified human resources in Indonesia.

In the implementation of English learning process, the researcher often found that the children at the Bilingual Kindergarten Rumah Pelangi Pondok Bambu often experienced difficulties in English pronunciation. They still lacked English vocabularies, and their English pronunciation was still incorrect. They assumed that English is difficult because its pronunciation seems strange and rarely used in everyday life. They also felt bored and less motivated to follow the English learning. Such low English proficiency in early childhood is due to family background that is less supportive to English learning, less attractive in using learning approaches, inappropriate selection of English language teaching materials in schools, less warm communication between the teachers and children, and less various use of media in learning English. Considering these constraints and the existing phenomena in the field, the researcher attempts to seek various techniques and strategies to help improve the children' mastery of English pronunciation at the Bilingual Kindergarten Rumah Pelangi Pondok Bambu. By engaging their senses of sight and hearing, especially with proper media utilization, it is expected that the lessons about English pronunciation can be more easily accepted by the children in a more enjoyable learning environment, so that they do not feel bored and more motivated to follow the English learning. Their English vocabulary and pronunciation mastery will become better because they hear directly from the media.

One of the learning activities that can introduce English is creative dance. In this dance, the children will learn to understand the song and recite it correctly. They will try to convey the information contained in the song and give expression according to the song like sad or happy expression. They will also practice the articulation and get additional vocabularies.

There are several aspects that can be examined through creative dance, such as: motoric (mouth movement) and verbal aspects. Verbal aspect is the prominent language aspect among children. They will gain new words and continue to recite them with the music in which it will make them faster to memorize the song. When singing, they will also try to make the listeners understand what they are saying.

Ability lies within human being. According to Robins ability is an individual capacity to perform tasks in a particular work. In addition, according to Gibson ability is an individual possession to perform tasks or jobs that are charged to him. Meanwhile, according to Chaplin ability is capability, skill, dexterity, talent, and capacity, which is the power to accomplish a work. It can be concluded that ability is the power that lies in every individual to work and accomplish something or an activity given to the person. Language skill is one of the abilities that exist in human beings.

Language is closely related to human cognition in which it becomes the highest cognitive function. According to Robinson children in the age range of 3-6 years old learn new words through the process of imitation of the voices heard. The imitation process is different from those aged 2-3 $1 / 2$ years old or those aged 4-6 years old. The former group's imitation process is only through sound, but the latter group's imitation process has something to do with additional efforts to understand what the meaning of the sound is. Early childhood is the golden age where children can easily absorb anything received from outside compared to the adults' brain, which is losing the ability to absorb a new language from the environment. Children aged 4 years old like to talk about detailed and scientific things. According to Jahja Yudrik regarding the development of children aged 4-5 years old, they love to talk because it is in accordance with the nature of the stage; that is the development of their language skill. They are able to utilize the vocabularies from the process of recording and reminding the words that they just received.

When learning English as the second language, the early-childhood children remain in their nature as Ann Miles Gordon said that "the child's culture, unique temperament, and learning style play a part as well." According to Ida Vera learning English especially in early childhood emphasizes more on the introduction of basic commands (basic instructions) and knowledge of the objects' names or objects around them (vocabulary). Early childhood naturally related to the world of play within which the teachers can slip English learning into the process, so that the children are unconsciously learning English.

The children aged 4-5 years old are able to learn English through the use of English words and sentences that aim to communicate with other people where human thoughts and feelings are symbolized in order to convey the meaning to them. However, they still have some difficulties on some English letters. At this age stage, they are able to deal with language learning because they are in the golden age, although they still experience errors in pronounciation, such as "I" and "R" as well as grammar. According to David Brazil pronounciation is intended for the English users who wish to be confident with their ability in speaking. It means that 
pronunciation is intended to be used by the people who speak English to be more confident with their own ability. Children are able to use polite sentences in communicating with others and to understand what others are talking about even with the language they just heard.

According to Anete Vasquez, English language has certain learning stages for its learners.

Table I

Developmental Stages of English Learners

\begin{tabular}{|c|c|c|c|c|}
\hline & $\begin{array}{l}\text { Preproducti } \\
\text { on }\end{array}$ & $\begin{array}{l}\text { Early } \\
\text { Producti } \\
\text { on }\end{array}$ & $\begin{array}{l}\text { Speech } \\
\text { Emergent }\end{array}$ & $\begin{array}{l}\text { Intermedia } \\
\text { te Fluency }\end{array}$ \\
\hline $\begin{array}{l}\text { English } \\
\text { learner } \\
\text { linguisti } \\
\text { c ability }\end{array}$ & $\begin{array}{l}\text { "Silent } \\
\text { period point } \\
\text { respond } \\
\text { with } \\
\text { movement. } \\
\text { Follow } \\
\text { command } \\
\text { receptive } \\
\text { vocabulary } \\
\text { up to } 500 \\
\text { words }\end{array}$ & $\begin{array}{l}\text { One - or } \\
\text { two- word } \\
\text { response } \\
\text { s. } \\
\text { Labeling. } \\
\text { Listing. } \\
\text { Receptiv } \\
\text { e } \\
\text { vocabular } \\
\text { y up to } \\
1000 \\
\text { words } \\
\text { Expressiv } \\
\text { e } \\
\text { vocabular } \\
\text { y } 100- \\
500 \\
\text { words }\end{array}$ & $\begin{array}{l}\text { Short } \\
\text { phrases and } \\
\text { sentences } \\
\text { Comparing } \\
\text { and } \\
\text { contrasting } \\
\text { Descriptions } \\
\text { Receptive } \\
\text { vocabulary } \\
\text { up to } 7000 \\
\text { words } \\
\text { Expressive } \\
\text { vocabulary } \\
2000 \text { words }\end{array}$ & $\begin{array}{l}\text { Dialogue } \\
\text { Reading } \\
\text { academic } \\
\text { text } \\
\text { Writing } \\
\text { Receptive } \\
\text { vocabulary } \\
\text { up to } \\
12000 \\
\text { words } \\
\text { Expressive } \\
\text { vocabulary } \\
4000 \\
\text { words }\end{array}$ \\
\hline $\begin{array}{l}\text { Teachin } \\
\mathrm{g} \\
\text { strategi } \\
\text { es }\end{array}$ & $\begin{array}{l}\text { Yes/ no } \\
\text { questions } \\
\text { Simplified } \\
\text { speech } \\
\text { Gestures } \\
\text { Visuals } \\
\text { Picture } \\
\text { books } \\
\text { Word walls } \\
\text { KWL charts } \\
\text { Simple } \\
\text { cloze } \\
\text { Activities } \\
\text { Realia } \\
\text { TPR }\end{array}$ & $\begin{array}{l}\text { Question } \\
\text { s that } \\
\text { require: } \\
\text { yes/no; } \\
\text { either/or; } \\
\text { two-word } \\
\text { response } \\
\text {; list of } \\
\text { words; } \\
\text { definition } \\
\text { s; } \\
\text { describin } \\
\text { g } \\
\text { Reader's } \\
\text { theatre } \\
\text { Drama } \\
\text { Graphic } \\
\text { organizer } \\
\text { s }\end{array}$ & $\begin{array}{l}\text { How and } \\
\text { why } \\
\text { questions } \\
\text { Modeling } \\
\text { Demonstrati } \\
\text { ng } \\
\text { Cooperative } \\
\text { Learning } \\
\text { Comprehens } \\
\text { ion } \\
\text { Checks } \\
\text { Alternative } \\
\text { Assessment } \\
\text { s } \\
\text { Simulations }\end{array}$ & $\begin{array}{l}\text { Brainstormi } \\
\text { ng } \\
\text { Journal } \\
\text { writing } \\
\text { Literary } \\
\text { analysis } \\
\text { Problem } \\
\text { solving } \\
\text { Role } \\
\text { playing } \\
\text { Monologue } \\
\text { s } \\
\text { Story } \\
\text { telling } \\
\text { Oral } \\
\text { reports } \\
\text { Interviewin } \\
\text { g and } \\
\text { application } \\
\text { s }\end{array}$ \\
\hline
\end{tabular}

English vocabularies owned by children aged 4-5 years old are also still limited because they are just learning the language for 6 months. According to Lisa French vocabulary is the collection of words heard and read. So, when they are just learning English for 6 months, it depends on the length of time they have studied it. The prominent thing at this stage is the children's abilities to speak and listen, according to Brewer that reading and writing are the linguistic activities. Thus, the development of spoken language is important to succeed the initial literacy meaning that the early literacy in early childhood is speaking, while the continuation of this is reading and writing. Furthermore, according to Palmer \& Bayley Oral language encompasses the ability to listen, speak, and communicate effectively. Spoken language is the basic one on which strong literacy is built including the ability to listen, speak, and communicate effectively. It is a solid foundation for literacy in which it also includes listening.

Creative dance can make the children express their feelings through movement, and it can trigger self-satisfaction. According to Vesna Gersak creative dance is an approach to children where they can use movement to express, create, and form a variety of contents which are educating. This movement is expressed while playing.

Dancing is a fun activity because children move freely, so they will feel happy when doing creative dance. According to Lykesas creative dance is a form of teaching and teaching approach that supports kinesthetic development of someone. Meanwhile, according to Gayle creative dance is a dance category in which humans explore the movement. It can be concluded that singing is fun because children love the song and makes them feel happy. Sometimes unconsciously when the children are listening to music, they will move. Then, when gathering with their friends, they will perform creative dance. In addition they unconsciously gain new vocabularies and repeat them continuously. Thus, creative dance is one of the teaching materials that is done by using movements or musical instruments, so that the children will feel happy, not bored and simultaneously get new vocabularies.

Furtherly described by Karen creative dance is an opportunity given to the children, so that they make a unique movement in accordance with the structure or problems assigned by the teachers. They are given the freedom to make moves in accordance with the problems assigned by the teachers.

Furthermore, according to Gilbert creative dance is a dance formed by various artistic movements that show expressions. This dance shows the individual's self and expresses what is perceived by the individual.

According to Jamariah creative dance is something that is not competitive, done spontaneously because the children will express their emotion and tell a story through the movement. This dance is formed by spontaneous movements, and they can express their emotions through dancing.

More specifically according to Lynette creative dance is done to develop the creative, physical, mental, and artistic aspects of a person in 
life. When performing the movements to create a beautiful dance, the human body exerts energy, and the formation of the pattern must also be adjusted to the right time. Thus, this dance manages a movement, and it develops togetherness since it focuses on cooperation between people.

\section{Methodology}

This research was conducted at Bilingual Kindergarten Rumah Pelangi Pondok Bambu located at Gading Raya Street, Pondok Bambu, East Jakarta. It was done in the academic year 2015-2016 in April, 2016 through 2 cycles. The first cycle was done seven times, while the second cycle was done four

\begin{tabular}{|c|c|c|}
\hline Pre-research & Cycle I & Cycle II \\
\hline $42,34 \%$ & $61,87 \%$ & $80,41 \%$ \\
\hline
\end{tabular}

times. At that time, the learning activities were effective, so it could help obtain adequate data.

This research employed Kemmis' and Taggart's classroom action research (CAR) model. The implementation process includes: a) planning, b) action, c) observation, and d) reflection. The rationale of employing this model because the researcher wanted to be the teacher in the classroom, while doing a research, so that direct involvement was done to see the manifestation of changes among the participants. They were seven children aged 4-5 years old at Bilingual Kindergarten Rumah Pelangi Pondok Bambu.

The sources of data in this study were from the participants in group A and the classroom teacher at Bilingual Kindergarten Rumah Pelangi Pondok Bambu, East Jakarta. The results of the observation that will be described was about the children's English proficiency before being given the action; the children's English proficiency when being given the action, and the children's English proficiency after being given the action.

Data collection techniques used in this study include: observation, interview, and documentation. Observation of the participants was done to make the data obtained be more complete, accurate, and richer in meaning of each behavior that appeared in the observation sheet conducted by the researcher. Interview was conducted by doing a question-answer session with the related parties, such as: parents, classroom teachers, and principals.

Documentation became a complementary tool of observation and interview which includes written works, pictures, or photographs. The techniques used in analyzing the data in this research were qualitative and quantitative ones. The analysis for qualitative data was done by analyzing the field notes made by the researcher during the learning process supported by documentation in the form of photos. Meanwhile, the analysis for quantitative data was done by calculating the development of the children's English proficiency. Therefore, both analyses were done to see whether the effect of creative dance on the English ability among children aged 4-5 years old manifests.

\section{RESULTS AND DISCUSSION}

The research results at Bilingual Kindergarten Rumah Pelangi Pondok Bambu showed that creative dance can improve the English ability of the children aged 4-5 years old with the last overall score as much $80.41 \%$.

\section{Table II}

The research results at Bilingual Kindergarten Rumah Pelangi Pondok Bambu

The results of the observation showed that the children's English ability at Bilingual Kindergarten Rumah Pelangi Pondok Bambu was not optimal because they had difficulty in saying the English words in which they also lack of English vocabularies. It was because the background of the children is not from family who uses English for daily communication, and the teachers often used Indonesian language in teaching.

The Bilingual Kindergarten Rumah Pelangi Pondok Bambu still applied classical learning method; that is using worksheet and pencil. Every day the children are given a worksheet so that they look bored. In addition, because the teachers often use Indonesian language, the English language skills of the children become less honed.

Based on the pre-intervention observation, the percentage of the children's English proficiency prior to the use of creative dance was as much $42.34 \%$. Meanwhile, after given such action, the percentage increased to $61.87 \%$ in cycle I and in cycle II to $80.41 \%$.

This increase manifested in some aspects of English: listening and speaking. The following are the data of each participant in cycle I. Respectively, they got $61.6 \%, 65 \%, 61.6 \%, 60 \%, 63.3 \%, 63.3 \%$, and $58.3 \%$. The data showed that each child was improving. Below is the percentage table of preintervention and cycle I.

After the first cycle, cycle II was conducted. In this second cycle, every child increased. The following are the data of each participant in cycle II. Respectively, they got $81,6 \%, 85 \%, 85 \%, 73,3 \%$, $78 \%, 80 \%$, and $80 \%$. The data showed that each child was improving. Below is the percentage table of pre-intervention, cycle I, and cycle II. 


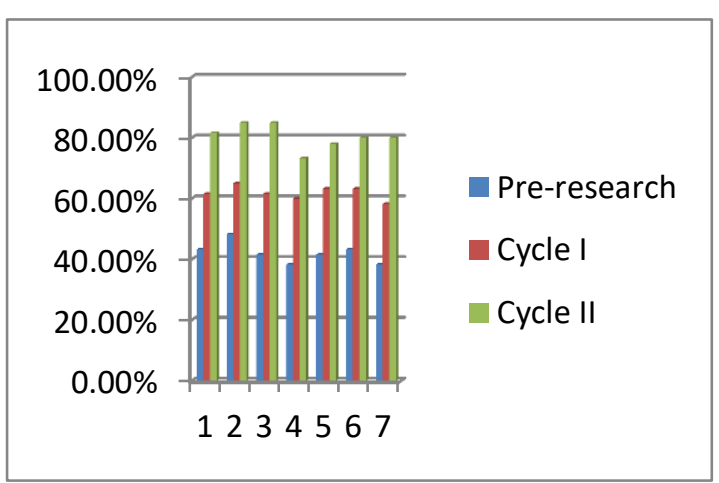

Skill

Fig. 1 Data on The Development of The Children's English Language

The quantitative analysis showed that the percentage of English language ability of the children increased to $80.41 \%$. It also showed the comparison between their ability before and after the action, although the development was not too high, but has exceeded the indicator of success established before the study took place as much $42.34 \%$. Thus, this research can be said successful because the children got a development as much $71 \%$. Therefore, the learning through creative dance can improve their English ability of group A at Bilingual Kindergarten Rumah Pelangi Pondok Bambu. The results of qualitative analysis proved that the creative dance helped improve their English language as well. Through this dance, they are able to improve their English ability to speak and respond in English. Providing creative dance as the action is one form of presentation of fun activities for them to develop their English skills optimally. Such dance not only develops their English skills, but also develops other aspects of development, such as: cognitive, motor, and emotional-social aspects of the children. So, the results to be achieved in English ability can increase significantly.

Table III

Intervention Guideline

\begin{tabular}{|l|l|l|l|l|l|}
\hline No & $\begin{array}{l}\text { Indicators of English Language } \\
\text { Skill for Children Aged 4-5 Years } \\
\text { Old }\end{array}$ & \multicolumn{3}{|c|}{ Scores } \\
\hline & & $\mathrm{BSH}^{*}$ & $\mathrm{~B}^{*}$ & $\mathrm{MB}^{*}$ & $\mathrm{BB}^{*}$ \\
\hline 1 & $\begin{array}{l}\text { Children can differentiate and } \\
\text { imitate certain sound/voice }\end{array}$ & & & & \\
\hline 3 & $\begin{array}{l}\text { Children can follow the teachers' } \\
\text { singing }\end{array}$ & & & & \\
\hline 4 & $\begin{array}{l}\text { Children can follow the teachers' } \\
\text { movements while singing }\end{array}$ & & & & \\
\hline 5 & $\begin{array}{l}\text { Children can retell experiences } \\
\text { in English }\end{array}$ & & & & \\
\hline 6 & $\begin{array}{l}\text { Children can give comments on } \\
\text { what is heard }\end{array}$ & & & & \\
\hline 7 & $\begin{array}{l}\text { Children can ask for questions in } \\
\text { English }\end{array}$ & & & & \\
\hline 8 & $\begin{array}{l}\text { Children can respond to what } \\
\text { the teachers give }\end{array}$ & & & & \\
\hline $\begin{array}{l}\text { Children can answer the } \\
\text { teachers' questions in English }\end{array}$ & & & & \\
\hline 9 & $\begin{array}{l}\text { Children can imitate the } \\
\text { sequence of words in English }\end{array}$ & & & & \\
\hline
\end{tabular}

\begin{tabular}{|c|l|l|l|l|l|}
\hline 10 & $\begin{array}{l}\text { Children can pronounce 3-4 } \\
\text { words in English correctly }\end{array}$ & & & & \\
\hline 11 & $\begin{array}{l}\text { Children can mention name, } \\
\text { sex, and home address in } \\
\text { English }\end{array}$ & & & & \\
\hline 12 & $\begin{array}{l}\text { Children can arrange and tell the } \\
\text { content of a series of pictures (4- } \\
\text { 6 pictures) }\end{array}$ & & & & \\
\hline 13 & $\begin{array}{l}\text { Children can pronounce and use } \\
\text { the words "Thank you, Excuse } \\
\text { Me, Good Morning, Good Bye" }\end{array}$ & & & & \\
\hline 14 & $\begin{array}{l}\text { Children can tell about the given } \\
\text { picture or their own picture in } \\
\text { English }\end{array}$ & & & & \\
\hline 15 & $\begin{array}{l}\text { Children can give reasons on } \\
\text { the events experienced by them } \\
\text { at school in English }\end{array}$ & & & & \\
\hline
\end{tabular}

*BSH=Berkembang Sesuai Harapan (Develop as Expected); B=Berkembang (Develop); MB=Mulai Berkembang (Start to Develop); BB=Belum Berkembang (Not Yet Develop)

The results of the intervention guideline analysis proved that the final scores for the seven children at Bilingual Kindergarten Rumah Pelangi Pondok Bambu are in the range of the categories B and BSH. The achievement of their English language has increased from pre-research, which was only in the range of the category $\mathrm{MB}$ and $\mathrm{BB}$ to $\mathrm{B}$ and $\mathrm{BSH}$. It can be said that all children experienced a significant development.

\section{CONCLUSION}

Based on the results of the data analysis showed that the obtained percentage of pre-research was as much $42.1 \%$; cycle I as much $61.87 \%$; and cycle II as much $80.41 \%$. The data can be said that the transitional percentage from pre-research to cycle I increased, but the interpretation of the results of the analysis is said to succeed if the development reaches the target of $71 \%$.

Based on the data of cycle II, the percentage of the children's English proficiency increased significantly. Therefore, it can be concluded that the creative dance can improve their English ability at Bilingual Kindergarten Rumah Pelangi Pondok Bambu, East Jakarta.

\section{REFERENCES}

Amin, Maswardi Muhammad. (2013). Pendidikan Karakter Anak Bangsa. Jakarta: Baduose Media.

Amin, Maswardi Muhammad. (2014). Moral Pancasila Jatidiri Bangsa. Jakarta: Gorga Media.

Arifin, Zaenal. (2009). Evaluasi Pembelajaran. Bandung: Remaja Rosdakarya.

Azhar, Arsyad. (2011). Media Pembelajaran. Jakarta: PT Raja Grafindo Persada. 
Endah, Alberthiene. (2013). Mimpi Sejuta Dolar. Jakarta: PT Gramedia

Fa'izia, Khilya dkk. (2015). Pendidikan Kewarganegaraan. Klaten: Intan Pariwara.

Hadi, Amirul dan Haryono. (1998). Metodologi Penelitian Pendidikan. Bandung: Pustaka Setia.

Kurniawan, Heru. (2012). Teori, Metode, dan Aplikasi Sosiologi Sastra. Yogyakarta: Graha Ilmu.

Kutha Ratna, Nyoman. (2013). Teori, Metode, dan Teknik Penelitian Sastra. Yogyakarta: Pustaka Pelajar.

Moleong, Lexy J. (2014). Metodologi Penelitian Kualitatif. Bandung: Remaja Rosdakarya Offset.

Nurgiyantoro, Burhan. (2013). Teori Pengkajian Fiksi. Yogyakarta: GAJAH MADA UNIVERSITY PRESS.

Nurgiyantoro, Burhan. (2014). Penilaian Pembelajaran Bahasa. Yogyakarta: BPFEYOGYAKARTA.

Purnama, Risma. (2014). Cooperative Learning. Pontianak. STAIN Pontianak Press.

Samani, Muchlas dan Hariyanto. (2014). Pendidikan Karakter. Bandung: Remaja Rosdakarya.

Siswantoro. (2014). Metode Penelitian Sastra. Yogyakarta: Pustaka Pelajar.

Sugiono. (2012). Metode Penelitian Pendidikan. 